https://doi.org/10.18485/kud_kiaz.2019.ch24

\author{
Фазиль Рустамов \\ Кандидат философских наук, доцент кафедры \\ «Философия и общественных наук» \\ Азербайджанского Университета Языков \\ rustemov_1969@mail.ru
}

\title{
ИДЕИ НАЦИОНАЛЬНО-КУЛЬТУРНОГО ОБНОВЛЕНИЯ В АЗЕРБАЙДЖАНСКОЙ ФИЛОСОФИИ ПРОСВЕЩЕНИЯ
}

\begin{abstract}
SUMMARY
Having been formed since the middle of the XIX century Azerbaijan enlightment becomes a new stage in the history of philosophical, social and political and literary - artistic thought in the enlightment of Azerbaijan. Basic principles as national character, patriotism, contemporaneity form the main point of this philosophy. Being initial national vigilance, national self - cognition philosophy, Azerbaijan enlightment has great significance and urgence as one of the scientifico - theoretical, ideologico - political sources of Azerbaijan national ideology.
\end{abstract}

Key words: enlighment, national idea, nationo-cultural innovation, the concept of personality, freedom, modernity.

Несмотря на все противоречия и лишения, вторая половина XIX и XX веков, которая составляет новую эру древней и богатой истории Азербайджана, национальное возрождение более заметно в процессе национально-культурного возрождения. Просвещение Азербайджана, которое является горьким выражением его воплощения в 
социально-философских и литературно-художественных взглядах, сыграло важную роль в формировании национального самосознания, национально-освободительной и независимой идеологии с ее национально-культурным обновлением, национальной самообеспеченностью, национальным возрождением, прогрессом и свободой.

Просвещение в истории человечества как «интеллектуального периода» является важным культурным и идеологическим феноменом перехода от новой эпохи к феодализму и капитализму в Азербайджане. Однако одна из главных особенностей азербайджанского просвещения заключается в том, что его создание и развитие обусловлено созданием и формированием национального самосознания народа. Борьба с национальным колониализмом укоренилась в воззрениях М. Ф. Ахундзаде, а позднее, в начале XX века, т. е. на заключительном этапе просвещения, она носила явный политический характер на уровне национально-освободительного движения. Просвещение было основной линией культурного и интеллектуального развития, характеризующей национальное самосознание в начале второй половины XIX-XX веков. В начале $\mathrm{XX}$ века революции в национально-общественном мнении Азербайджана способствовали такие политические тенденции, как демократия, национальная независимость и либеральная демократия.

Просвещение в Азербайджане - это не только введение в новое реалистическое мышление той эпохи, но и начало национально-пробуждающего движения, национальной самореализации, национально-культурного обновления. Национально-пробуждающее движение, идеи национально-культурного возрождения, прогресса и свободы и их вакцинация носили прежде всего просветительский характер. Играя важную роль в развитии азербайджанских социально-философских идей в новом направлении, означало, что возвращение патриотизма, национального пробуждения, обновления, прогресса и 
свободы было основным отражением национальных и философских мыслей. Все это, в свою очередь, заложило основу для формирования и заложения почвы национальной идеи.

Академик Рамиз Мехтиев пишет о сущности национальной идеи и ее историческом значении в своей статье «Современный Азербайджан является выражением национальной идеи»: «Идея национальной философии уже давно подтвердила, что национальная идея играет важную роль в жизни общества, политической практики и, следовательно, национальной идеи каждой нации. Нация не имеет права жить, а философы называют национальную идею концепцией национального самосознания, которая выражает судьбу народа, его задачи и мобилизует национальную энергию для решения судьбоносных вопросов.

Национальная идея - это не выдумка человека, она глубоко укоренилась в сознании людей, а социальная реальность подкрепляется конкретным историческим моментом ... Национальная идея - это общая цель и стратегия развития общества ... Следует отметить, что национальная идея впервые была разработана национальным сознанием, Умственный исход, обусловленный борьбой, формируется как общественная идея»[2].

Национальная идея - это не выдумка человека, она вытекает из глубины сознания людей, а социальная реальность поддерживает ее с определенной исторической точки зрения. Национальная идея - это общая цель и стратегия развития общества. Важно отметить, что национальная идея сначала возникает как национальная мысль, волна национального самосознания, психический результат, обусловленный борьбой за независимость и во имя независимости.

С этой точки зрения, идеи национально-культурного обновления, которые служат пробуждению национального самосознания азербайджанского просвещения и первые исторические шаги, предпринятые для их реализации, 
имеют исключительный вклад. В наших современных научных и философских исследованиях обосновывается такое убеждение, что проблема пробуждения национального сознания, связанная с судьбой нации, зависит от движения и растворения Азербайджана в истории социально-философской мысли. В связи с этим примечательно, что в своих ранних исследованиях профессор А.М. Ахмедов характеризовал азербайджанскую философию просвещения как «философию национального самосознания» [11, с.290]. В начале 20-го века на ранних этапах введения идеи национального пробуждения и культурного возрождения, имевшие характер просвещения, имели четкое политическое значение и ориентацию и заложили основу для формирования национального мышления.

Профессор А.М. Тагиев сказал в своей книге «Национальная идея и национальная идеология: проблемы и их интерпретация»: «Идея Азербайджана в научно-теоретическом, идейно-политическом источнике национальной идеологии Азербайджана включает в себя комплекс национально-нравственных ценностей, просвещающих азербайджанское просвещение» [8, с.23].

Академик Р.Мехтиев пишет в своей статье: «Со второй половины XXI века идея перехода от религиозной идентичности к этнической идентичности национальной идеи Северного Азербайджана, которая была частью Российской империи с 1828 года в результате войны с Ираном, находилась в центре поиска идей в этой области. В то время самой важной целью было отделить этническое сознание от религиозного сознания. В этом направлении работали такие мыслители 21 века, как А.А. Бакиханов, М.Ф. Ахундзаде, Мирза Казымбей » [2]. Во второй половине XIX и начале XX века Азербайджан был основным источником идей и лейтмотивом идей социокультурной модернизации, секуляризма, понимания необходимости национального возрождения и освобождения. С этой точки зрения в этот период возникли различные идео- 
логические тенденции, идеи национального движения А.А.Бакиханова и М.Ф.Ахундзаде были более прямыми $[7$, c.116]. Эта тенденция проистекала не из субъективных устремлений, а из внутреннего составляющего исторический процесс. В конце 19- начале 20 веков Х. Зардаби, М. Шахтахтли, А. Топчубашов, А.А. Агаоглу, А.Гусейнзаде, К.Мамедгулузаде, М.Сабир, М.Расулзаде, У.Гаджибеков, Ю.В. Чаманзаминли и другие выдающиеся педагоги, народные классики сыграли главную роль в пробуждении национального самосознания и национально-культурном возрождении азербайджанцев.

Как видно из истории, стремление каждой нации к свободе, прогрессу и независимости, как правило, находится в процессе самоцензуры, постепенно реалистичной, ясной, основанной на определенных теоретических идеях. А именно, национальное пробуждение, идеи национально-культурного обновления, которые являются основными потребностями этого процесса, постепенно превращают национальную идею в национальную идеологию.

Идеи национального просвещения получили на начальных этапах великие достижения, которые в будущем начали себя проявлять. Во второй половине 19 века национальный театр, национально-демократическая пресса, школы на родном языке и т. д. были первым крупным достижением за «культурную независимость» (М.Э. Расулзаде) и дали мощный импульс формированию национального самосознания [1, с.613].

Как моральное проявление процесса превращения азербайджанского народа в «бытие для себя», национальное единство умов и национальные идеи, направленные на его теоретическую направленность, пути формирования идеологии национального единства сталкиваются со сложной социальной средой шовинистического русского царизма, что стало вдвойне сложнее и противоречивее. C середины 19-го века идеи национально-культурного обновления, которые были созданы благодаря нацио- 
нальному пробуждению, прогрессу и свободе, которые в основном представляют собой образовательную среду, имеют особое значение.

Во второй половине XIX - начале XX веков в социально-экономической жизни Азербайджана формировались новые капиталистические отношения в социальной структуре, в направлении объективности на основе упадка старых феодально-патриархальных принципов. Новые «первенства», новые «изм»-ы и понятия формируются и становятся объектами серьезного мышления. Среди всех понятий, такие понятия как, «патриотизм», «национализм», «нация», «национальное единство» привлекает все больше внимания. Даже в начале 20 века в общественном достоянии Азербайджана, понятия «нация» и «национальность» не дошли до их полного понимания, но поиск идей национального пробуждения и религиозного сознания, традиционного патриотизма и мусульманского мышления имело очень важное место.

Возвышающаяся деятельность азербайджанского патриотизма, идея любви к родине-Азербайджану, в расширенной форме национальная сплоченность собирает в себе идею к свободе. Ахундзаде и др. в свое время имели знания о национальной сплоченности государства. Национальная сплоченность не призывала к пропаганде религии или демократической нестабильности, а призывала к сплоченности и единству народа, языка и культуры •

В конце 19-го века первые попытки поднять национальную самобытность на страницах газет «Экинчи», «Кешкюль» и «Каспи» показали необходимость национального самоопределения. Вопрос создания и влияния национальной идеи Азербайджана в этом отношении имел особое значение. По словам проф. А. М. Тагиева, исторические корни национальной идеи Азербайджана уходят в глубь веков. «Однако идея (М. Э. Разсулзаде) Азербайджана должна рассматриваться как продукт новой эры. Подъем национально-пробуждающего движения между русскими турками в 19-20 веках, особенно 
в Баку и Газахе, привел к утверждению и расширению границы между тюркской и азербайджанской интеллигенции “ $[8$, с.25]. Здесь также следует подчеркнуть роль демократических просветителей. Впервые они заложили краеугольный камень национальной идеи Азербайджана, которая является предметом такой полемики в Азербайджане, поскольку она привносит идею патриотизма, национальных амбиций, национального единства. Автор этой идеи, который первым ввел слова «азербайджанец» и «азербайджанский язык» в лексикон Магомедага Шахтахлы опубликовал в 1891 году в газете «Каспи» статью о том: «Как называть закавказских мусульман?». В своем ответе на тот же вопрос в своей статье он считает, что «... закавказских мусульман азербайджанцами, а закавказский тюркский язык татар было бы целесообразно называть азербайджанским языком» [10, с. 29].

В продолжении этой идеи М. Э. Расулзаде написал в серии статей под названием «Национальное пробуждение», опубликованных в книге «Дирилик» в 1914 году: «Многие цивилизации и племена имеют общую культуру, общий язык, которых можно назвать одной нацией азербайджанцев» [6, с.468].

Осуществление освобождения и независимости азербайджанского народа впервые в конце второго десятилетия двадцатого века Азербайджанской Демократической Республикой стало объективным логическим завершением поиска национальной идеи, национального пробуждения и национального самосознания. С помощью АДР, по словам М. Э. Расулзаде, «концепция азербайджанца в сознании людей воплощена в форме идей и поступков, а не географического смысла» [4, с.95], и превращается в политико-идеологическое образование. Благодаря своему 23-месячному присутствию в истории национальной самодостаточности, национальной идентичности и независимости, АДР доказало, что для народа Азербайджана «нет Азербайджана вне независимости» [4, с.95]. 
Азербайджанский народ, который был приговорен к тому, чтобы жить в тоталитарном советском режиме в течение 70 лет, в конце 20-го века вновь боролся за свою независимость и сумел восстановить свою национальную независимость.

В современный период Азербайджанская Республика успешно развивается на пути вечной и необратимости своей независимости на основе стратегии государственности, определенной общенациональным лидером Гейдаром Алиевым, и приобретает большое влияние на международной арене.

\section{Литература:}

Azərbaycan tarixi. I cild. Bak1, Azərnəşr, 1994.

Mehdiyev R. Müasir Azərbaycan milli ideyanın təcəssümü kimi. "Azərbaycan" qəzeti, 26 may 2011-ci il.

Məmmədzadə M.B. Milli Azərbaycan hərəkatı. Bak1, Nicat, 1992.

Rəsulzadə M.Ә. Azərbaycan Cümhuriyyəti. Bak1, Elm, 1990.

Rəsulzadə M.Ә. Đsrimizin Siyavuşu. Çağdaş Azərbaycan ədəbiyyatı. Çağdaş Azərbaycan tarixi. Bakı, Gənclik, 1991.

Rəsulzadə M.Ә. Әsərləri. II cild. Bakı, Şirvannəşr, 2001.

Tağıyev Ә.M. Milli ideya və milli ideologiya: problemlər və onların şərhi. Bak1, Təbib, 2000.

Tağıyev Ә.M. Azərbaycan ideyasının təsiri. "Sosial-siyasi problemlər (elmi məqalələr toplusu)". VIII buraxılış. Bak1, Qismət, 2003.

Talıbzadə K.A. Tənqid və tənqidçilər. Bakı, 1989.

Şaxtaxlı M. Seçilmiş əsərləri. Bakı, Çaşığlu, 2006.

Ахмедов Э.М. Философия азербайджанского просвещения. Баку, Азернешр, 1982.

Абдуллабекова г.г. Просветительство в азербайджане и европе. Баку,2016

История азербайджанской философии. Т.1. Баку, 2002.

История азербайджанской философии. Т.2. Баку, 2008.

Мамедов 3. История Азербайджанской философии. Баку, 1994.

Рзаев А .История политических и правовых учений в Азербайджане от истоков до XX века. Баку, 2000. 


\section{PЕЗЮМЕ}

Просветительство Азербайджана формируясь с середины XIX века становится новым этапом в истории философского, общественно-политического и литературно-художественного мыщления.Такие принципы как народность, патриотизм и модернизм являются сущностью философиипросвещения Азербайджана. Философия пробужденного национального сознания и понятие национального самоопределения играют особую роль в современном Азербайджанском просветительстве как один из научно-теоретических и идейно-политических источников современной национальной идеологии.

Ключевые слова: просветительство, национальная идея, культурно-национальное обновление, самосознание, азербайджанство, свобода, современность. 